\title{
放牧育成牛に対する駆虫剤投与の影響と光の経済効果
}

\author{
相沢知子・宮本賢一*1・吉田 徹・西野 豊・山根逸郎*2 \\ ${ }^{* 1}$ 埼玉県農林部畜産課 \\ *2農林水産省家畜衛生試験場疫学研究室
}

\section{A clinical trial to evaluate the effect of ivermectin injection for grazing heifers}

\author{
Tomoko AIZAWA, Kenichi MIYAMOTO*1, Toru YOSHIDA, Yutaka NISHINO and Itsuro YAMANE*2 \\ ${ }^{* 1}$ Livestock Division, Agriculture and Forestry Department, Saitama prefecture \\ *2 Laboratory of Epidemiology, National Institute of Animal Health Ministry of Agriculture, Forestry and Fisheries, \\ Ibaraki
}

(Received 10 May 1997/Accepted 20 June 1997)

\begin{abstract}
Summary
During 1995, a clinical trial was performed to evaluate the medical and economical effects of ivermectin administration for grazing heifers at one public farm, Saitama prefecture. Animals, which were entered for the grazing in spring, were classified into 3 blocks (A, B, C) based on their age and body weight. In each block, animals were randomly allocated into administration ( 5 times ivermectin injections) and non-administration groups. Daily body weight gain, hematocrit values, number of animals with Theileria infections, conception rates and economical effects were evaluated between two groups. In low age block, animals with ivermectin administration had significantly higher daily body weight gain and hematocrit values compared to nonadministrated animals, however, no significant differences were observed in the number of animals with Theileria infections and conception rates. In other age blocks, improved daily body weight gain were constantly observed in ivermectin administrated groups, however, no statistical differences were detected. Because of the improved daily body weight gain, the management strategy using ivermectin administration was economically useful for the grazing heifers, especially when it was used for young animals.
\end{abstract}

近年，放牧衛生対策としての薬棛に広域の抗寄生虫又 ペクトラムを持つアベルメクチン $\mathrm{B} 1$ の誘導体であるイ ベルメクチン製剤が注目されている1”。その製剂は牛の 内部寄生虫 ${ }^{12,15)}$ および牛の疥癬ダニの駆虫 ${ }^{11}$ に有効であ ることが周知され，1994年にはイベルメクチン製剤の投 与がピロプラズマ病の防疫に有効であったと報告されて いる7。

そこで今回，当場におけるイベルメクチン製剤の放牧 衛生対策としての効果を調べるために, 臨床試験を用い て検討を行った。さらに得られたデー夕を基に当衛生対 策の経済効果について検討を行った。

埼玉県秩父高原牧場

干355-03 埼玉県秩父郡東秩父村坂本2951

Chichibu Highland Farm in Saitama prefecture , 2951 Sakamoto, Higashichichibu - mura, Chichibu - gun, Saitama 355-03, Japan

\section{材料および方法}

\section{牧場の概要}

埼玉県秩父高原牧場は埼玉県北西部の標高 $270 \mathrm{~m}$ から $767 \mathrm{~m}$ に位置し，総面積355ha，内放牧地 $207 \mathrm{ha} ， 5$ つの放 牧区を有する県内唯一の公共育成牧場である。当場では 通年 4 月に, 県内の酪農家から生後 6 ヶ月から 12 ケ月齢の ホルスタイン種雌子牛約 200 頭を受け入れ，2週間の馴致 放牧の後, 春期から秋期は放牧地，冬期はフリーストー ル牛舎にて飼養管理し，次年 9 月までに人工授精，受精 卵移植を実施して妊娠を確認した上で受託牛を返却する 業務を行っている。

当場では1980年よりピロプラズマ病による被害が多発 し，大きな経済的損失を被ってきた。ピロプラズマ病は フタトゲチマダニによって媒介されるTheileria sergenti の感染により引き起こされ，発熱抢よび筫血を主徵とす 
る原虫性疾患である。Theileria sergenti感染牛は通常は 臨床症状を呈さず, 牧野における飼料, 環境の急変, 多 疾病の混合感染, 妊娠等のストレスによりピロプラズマ 病として発症する場合が多い4。当場では, 牧野のダ二の 污染ひいてはT.sergenti感染牛の防除のため, 過去には8 ーアミノキノリン製剤の感染牛への投与, $0.1 \%$ 有機リン 系殺ダ二剂水溶剂による牛体の消毒，イアータッグの使 用, 夏期の全頭一斉牛舎収容, 放牧地へのカーバメイト 系粒剂, 有機リン系粒剂の空中散布, カーバメイト系粉 剂の地上散布等が試みられたが11), 著しい効果は得られ ず，耐性が生じた例もあり現在では実施されていない。 1989年度よりピレスロイド系油剤の背線への塗布 (pour-on)によるピロプラズマ病撲滅対策を試験的に 実施し, 受託牛の全頭投与を開始した1992年度以降ピロ プラズマ病発症頭数は年間10数頭に低下し，1994年度は 3 頭の発症に抑之られている5”。しかしながら, 本病未感 染で入牧した牛のほぼ全頭が受託期間中にT.sergenti感 染牛となるなど, 当場の受託牛が常時本原虫に暴露され ている状況に変わりなく, ダ二の薬剂耐性の獲得や, 気 候, 環境等の急変で本病が急增することが懸念され，今 後さらなる発症率や感染牛の減少を目指したピロプラズ マ病対策の実施が期待されている。

\section{試験期間および試験対象動物}

試験期間は1995年 4 月から 12 月までとした。試験対象 動物は, 1995年度新規受託牛の内, 入牧時の衛生検查に おいて, 臨床的に健康・ Ht 值が $30 \%$ 以上・原虫寄生度陰 性であることの 3 条件を満たした77頭とし， 入牧時月齢 及び体重測定值の高い順から $\mathrm{A}, \mathrm{B}, \mathrm{C} の 3$ ブロックに 分けた。そして, ブロック毎にイベルメクチン投与群と 非投与群の頭数の構成比が概ね 2 対 1 の割合になるよう 牛群を設定した(表 1 )。各ブロックはそれぞれ異なる放 牧区で飼育されたが, ブロック内の投与群と非投与群は 同一放牧地，同一条件下で飼養管理された。

\section{投与法および日程}

イベルメクチン投与群は 5 月， 6 月， 7 月， 8 月，牛 舎収容前の 10 月の計 5 回, イベルメクチン製剤を 1 回1頭 当たり規定量 $(200 \mu \mathrm{g} / \mathrm{kg})$ 肩部に皮下注射した。また, 投与群と非投与群は全頭, 通常の放牧衛生対策として 5 月から 10 月までの放牧期間中 2 週間に 1 度合計 13 回, ピ
レスロイド系油剤を1回1頭あたり規定量 $(10 \mathrm{ml} / 100$ $\mathrm{kg})$ 牛の背中線上に沿って頭頂部から尾根部にかけて滴 下した。また，投与量を決めるための体重の值は，入牧 時， 6 月， 8 月，10月に測定したブロック別体重平均值 を参考にして設定した。(表 2 )

\section{測定項目}

試験に際しては，下記項目についてブロック毎に投与 群と非投与群を比較検討した。

(1) 日增体量 ( $\mathrm{g} /$ Day : 以下D.G)

入牧時， 6 月， 8 月， 10 月， 12 月に体重測定を行った。 入牧時から 6 月， 6 月から 8 月， 8 月から 10 月， 10 月か ら12月，入牧から 12 月の体重差からその期間の日数を除 し, 日増体量を求めた。

(2) ヘマトクリット値 ( $\mathrm{Ht}$ 值)

ピレスロイド系油剤投与の際, 尾静脈より採血し直ち に血液をへパリン処理した毛細管に満たした後，1分間 11,000回転で5分間遠心して目盛板で測定し, へマトク リット值を求めた。

(3) 原虫陽転率

ピレスロイド系油剤投与の際, 尾静脈より採血し直ち に血液薄層塗沫標本を作製し，ギムザ染色後顕微鏡下で 石原の方法による原虫寄生度の評価）を行い，一から十 までを㓌性，+十以上を陽性に分類した。尚，全放牧期 間を通して一度でも陽性となった個体をピロプラズマ陽 転個体として，陽転率を求めた。

(4) 受胎成績

受託期間中に妊娠を確認した牛について，受胎に至る

表 1 試験対象群

\begin{tabular}{ccccc}
\hline \multirow{2}{*}{ 区 } & \multirow{2}{*}{ 分 } & \multirow{2}{*}{ 頭数 } & \multicolumn{2}{c}{ 入牧時デー夕 } \\
\cline { 4 - 5 } & & & 月齢 & 体重 $(\mathrm{kg})$ \\
\hline \multirow{2}{*}{$\mathrm{A}$} & 投 与 群 & 16 & 11.8 & 264.1 \\
& 非投与群 & 6 & 12.6 & 266.0 \\
\multirow{2}{*}{$\mathrm{B}$} & 投 与 群 & 18 & 10.4 & 233.3 \\
& 非投与群 & 10 & 10.2 & 233.6 \\
\multirow{2}{*}{$\mathrm{C}$} & 投 与 群 & 18 & 8.1 & 187.0 \\
& 非投与群 & 9 & 8.3 & 181.2 \\
\hline
\end{tabular}

表 2 投与及び検査日程

\begin{tabular}{|c|c|c|c|c|c|c|c|c|c|c|c|c|c|c|c|c|}
\hline & & & & 4 & & 5 & 6 & & 7 & & 8 & & & 9 & $\begin{array}{lll}10 & 11 & 1\end{array}$ & 12 \\
\hline & $x$ & ・ン齐 & & & & 0 & 0 & & 0 & & & 0 & & & 0 & \\
\hline 採 & & & 血 & $\triangle$ & $\triangle$ & $\triangle \Delta$ & $\triangle$ & $\triangle$ & $\triangle$ & $\triangle$ & $\triangle$ & $\triangle$ & $\triangle$ & $\triangle \Delta$ & $\triangle$ & \\
\hline 体 & 重 & 測 & 定 & $\diamond$ & & & $\bullet$ & & & & $\diamond$ & & & & $\diamond$ & \\
\hline & & & & $\begin{array}{c}\text { 方 } \\
\text { 入牧 }\end{array}$ & & $\begin{array}{l}\text { 佟日放物 } \\
\text { 等 }\end{array}$ & & & & & & & & & $\begin{array}{l}\widehat{v} \\
\text { 牛舎収容 }\end{array}$ & \\
\hline
\end{tabular}


までに要した授精回数で分類した。

(5) 経済評価

各ブロックの投与群と非投与群のD.G.より，授精開 始基準体重である $330 \mathrm{~kg} に$ 成育するまでの日数を算出し, 両群の日数の差を 1 日610円の預託料に換算して, 増体量 の差による経済効果の評価とした。また， 1 頭当たりの イベルメクチン製剂の価格, 使用器具, 機材および人件 費を投与にかかる費用とし，それらの数值を増体量の差 による経済効果より差し引いた。

\section{統計検定}

全項目有意水準 $5 \%$ で検定し, D.G, Ht值については t 検定を, 原虫陽転率はFisherの直接確立検定, 受胎成績は Mann-Whitney のU検定を用いた。なお，統計ソフトは Microsoft社Excel 5.0及びAbacus社Stat View 4.5を使 用した。

\section{成 績}

(1) D.G.

各ブロックの入牧から 12 月測定時までの投与群と非投
0与群のD.Gの差は, A 256g/day, B 359g/day, C 729 $\mathrm{g} /$ dayで，Cブロックは全放牧期間を通した増体量にお いて，投与群が非投与群より有意に高かった。 A， B ブ ロックでは統計的有意差は観察されなかったものの，全 体に投与群が非投与群より高い傾向を示した。（表 3 ）

\section{(2) $\mathrm{Ht}$ 值}

投与群, 非投与群とも 5 月に一度急激に下降した後, 再び上昇して 7 月にピークを迎え，その後は緩やかに下 降する同一のパターンで推移していた。ブロック別に見 た場合，A， Bブロックに比し，Cブロックでは投与群 の方が非投与群より高い值を示す傾向が見られた。(図 1 )

(3) 原虫陽転率

全放牧期間を通して, 各ブロックの投与群, 非投与群 ともに多くの動物が小型ピロプラズマ原虫に感染し, 各 ブロックとも, 投与群, 非投与群の間に有意な差は認め られなかった。(表 4 )

(4) 受胎成績

各ブロック共，投与，非投与群の間に有意な差は認め られなかった。(表 5 )

(5) 経済評価

表 3 入牧から 12 月までの増体重及びデイリーゲイン

\begin{tabular}{|c|c|c|c|c|c|c|c|}
\hline \multirow{2}{*}{ 区 } & \multirow{2}{*}{ 分 } & \multirow{2}{*}{ 増体重kg } & \multicolumn{5}{|c|}{ デイリーゲイン g/Day } \\
\hline & & & 4 月 -6 月 & 6 月 -8 月 & 8 月 -10 月 & 10 月 -12 月 & 4 月 -12 月 \\
\hline & 投与 群 & 155.2 & 207.3 & 922.9 & 568.9 & 1098.2 & 680.6 \\
\hline & 非投与群 & 149.3 & 297.2 & 783.3 & 514.1 & 1105.4 & 655.0 \\
\hline \multirow{2}{*}{ B } & 投与 群 & 172.4 & 477.8 & 704.6 & 922.8 & 959.2 & 756.1 \\
\hline & 非投与群 & 164.2 & 500.0 & 615.0 & 796.6 & 1026.5 & 720.2 \\
\hline & 投 与 群 & $* 189.8$ & 656.5 & $* 582.4$ & 1055.6 & 859.4 & $* 783.9$ \\
\hline & 非投与群 & 162.1 & 579.6 & 498.1 & 988.7 & 798.2 & 711.0 \\
\hline
\end{tabular}

*有意義有り $(\mathrm{p}<0.05)$
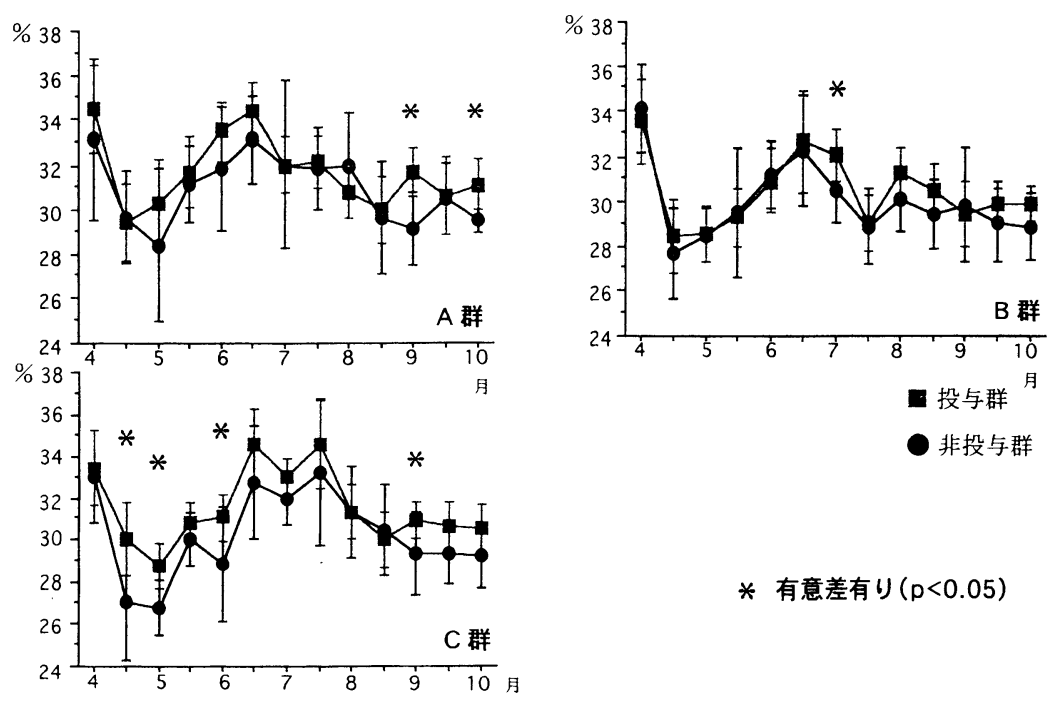

図 $1 \mathrm{Ht}$ 值平均值の推移

* 有意差有り $(p<0.05)$ 
表 4 原虫陽転率

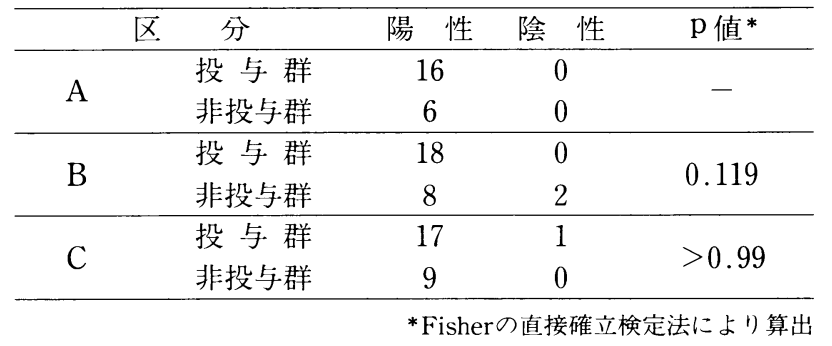

表 5 受胎成績（受胎に要した受精数）

\begin{tabular}{|c|c|c|c|c|c|c|}
\hline E & 分 & 1 回 & 2 回 & 3 回 & 4回以上 & $\mathrm{p}$ 值 ${ }^{*}$ \\
\hline \multirow{2}{*}{ A } & 投 与 群 & 9 & 2 & 2 & 3 & \multirow[b]{2}{*}{0.3966} \\
\hline & 非投与群 & 5 & 0 & 0 & 1 & \\
\hline \multirow{2}{*}{ B } & 投 与 群 & 10 & 5 & 1 & 2 & \multirow{2}{*}{0.3026} \\
\hline & 非投与群 & 4 & 2 & 1 & 3 & \\
\hline \multirow{2}{*}{$\mathrm{C}$} & 投与 群 & 7 & 6 & 0 & 5 & \multirow{2}{*}{0.9385} \\
\hline & 非投与群 & 4 & 2 & 1 & 2 & \\
\hline
\end{tabular}

表 6 イベルメクチン投与による 1 頭当たりの経済効果

\begin{tabular}{|c|c|c|c|c|c|c|c|c|c|c|c|}
\hline \multirow{2}{*}{ 区 } & \multirow{2}{*}{ 分 } & \multirow{2}{*}{$\begin{array}{l}\text { 330kgに成 } \\
\text { 育するまで } \\
\text { の推定日数 }\end{array}$} & \multirow{2}{*}{$\begin{array}{l}\text { 日数差 } \\
\text { (日) }\end{array}$} & \multirow{2}{*}{$\begin{array}{c}\text { 預託料換算 } \\
\text { (円) (年) }\end{array}$} & \multirow{2}{*}{$\begin{array}{c}\text { 全投薬量** } \\
(\mathrm{ml})\end{array}$} & \multirow{2}{*}{$\begin{array}{c}\text { 薬剂価格** } \\
\text { (可) (b) }\end{array}$} & \multicolumn{3}{|c|}{ 雑費 (円) $* * \mid \mathrm{c}$} & \multirow{2}{*}{$\begin{array}{c}\text { 人件費 ** } \\
\text { (问) id }\end{array}$} & \multirow{2}{*}{$\begin{array}{r}\text { 経済効果 } \\
\text { (円) (e) }\end{array}$} \\
\hline & & & & & & & 注射筒 & 注射針 & 酒精綿 & & \\
\hline A & 投与群 & 96.1 & 3.8 & 2290.9 & 30.0 & 35850 & \multirow{4}{*}{104.0} & \multirow{4}{*}{28.5} & \multirow{4}{*}{1.0} & \multirow{4}{*}{135.5} & -1.563 .1 \\
\hline & 排投与碃 & $\begin{array}{l}99.8 \\
127.8\end{array}$ & & & & & & & & & \\
\hline B & 非投与群 & $\begin{array}{l}121.8 \\
134.1\end{array}$ & 6.4 & $3,884.8$ & 28.5 & 3.405 .8 & & & & & 210.0 \\
\hline & $\begin{array}{l}\text { 投 与 群 } \\
\text { 非投与群 }\end{array}$ & $\begin{array}{l}194.3 \\
214.2\end{array}$ & 20.0 & $12,166.5$ & 24.0 & $2,868.0$ & & & & & $9,030.0$ \\
\hline
\end{tabular}

* 端数は四唅五入

**投薬量、薬剂価格、雑費、人件費は全 5 回分

1頭あたりの経済効果の算出方法 （体重330 kgに成育するまでを基準として）

\section{預託料換算}

= (非投与群の推定日数一投与群の推定日数 $) \times\ulcorner 1$ 日あたりの預託料 $(610 円) 」$

(a)

薬剂価格 $=\ulcorner$ 全投薬量 $\lrcorner \times\ulcorner$ 単価 $119.5($ 円 $/ \mathrm{m})\lrcorner$

杂隹 費 $=\ulcorner$ 注射筒代」 $+「$ 注射針代」 $+「$ 酒精綿代」

(b)

(c)

人件費（1日 8 時間労働、 1 時間 60 頭投与可能として 1 頭当たりに掛かる人件費) $=「$ 獣医師 1 日雇い入れ代 13,010 円」 $\div 8$ 時間 $\div 60$ 頭 $\times$ 投与回数 $(5$ 回 $)$

経済効果 $=(\mathrm{a})-\{(\mathrm{b})+(\mathrm{c})+(\mathrm{d})\}$

投与群と非投与群における増体量の差による経済効果 と、イベルメクチン投与にかかる費用を差し引いたもの を表 6 に示した。入牧時の月齢, 体重が最も低かったC ブロックにおいて，イベルメクチン投与による経済効果 が最も高く表れ，入牧の月齢，体重が低かったAブロッ クでは，経済的正当性が得られなかった。（表 6 ）

\section{考察}

今回の臨床試験において，イベルメクチン製剂の投与 が若齢の放牧牛の増体に良好な効果があることが示唆さ れた。放牧牛の增体に影響を与える要素として，飼料， 放牧牛の素因，天候，ストレスなど各種が考えられた。 しかし，今回の試験においては，試験開始時点で投与群 と非投与群の月齢や体重の平均が均等になるように設定 され，また両群とも同一の放牧地に放牧されているため， 両群の増体量の差が投与条件以外の要因による可能性は 低いものと考之られた。消化管内線虫の放牧牛への病原 性として, 感染幼虫の養分摂取, 粘膜損傷作用による消
化酵素の活性化の阻害，幼虫移行による組織傷害作用な ど，また鉤虫や捻転胃虫などの成虫による吸血作用や牛 の消化栄養素の吸収，免疫系への刺激によるアレルギー 反応などが挙げられる ${ }^{2 !}$ 。さらに，多数の消化管内線虫の 寄生による腸管の炎症および消化ホルモンなどの作用に より，摂食量が減少し，増体や泌乳に影響を与えると言 うことが知られている2!。イベルメクチン剤は，抑制性神 経伝達物質である $\gamma^{-}$amino-butyric acid（GABA）に作 用し，神経伝達を抑制的に阻害して寄生虫を麻症させる 効果がある6!。従って今回の試験では，イベルメクチン投 与による消化管内線虫の駆虫効果により，イベルメクチ ン投与群の増体量が高く維持されたものと考之られた。 これは，過去に試験的がおこなわれた育成牛へのイベル メクチン投与試験の結果と類似するものであった 2.3.7.13!。 さらに，入牧時の月齢，体重は共に若い群に特に顕著な 増体の差を示したことは，育成牛に対する消化管内線虫 駆除に関する過去の報告と一致する ${ }^{15}$ 。。これは放牧育成 牛の体重が若い時期に急速に増加するため ${ }^{16}$, 特に駆虫 
薬の増体への効果が若齢の動物群に大きく表れること, および消化管内寄生虫感染症の病原性が, 若齢の動物群 に強く表れることなどがその可能性として考えられた。

ヘマトクリット值が，イベルメクチン投与群に扔いて 高い値を示した原因は，消化管内線虫の防除により栄養 吸収などが良好となり，その結果放牧牛の免疫機能が活 性化し，ピロプラズマ原虫の赤血球破壊作用を低く抑之 たことであると考えられた。過去の類似する試験でも， 消化管内線虫の増殖を抑之高い増体量を維持することに より，ピロプラズマ症を抑える効果が報告されている゙。 今回の試験では, 当放牧場の牛群に寄生する線虫の種類 の同定はなされていないが，鉤虫や捻転胃虫など吸血性 の線虫が多数寄生している場合においても，それらの駆 除がへマトクリット值に大きな影響を与えるものと考之 られた。

ピロプラズマ原虫陽転率に両群有意な差が観察されな かったのは，イベルメクチン剂が抗ピロプラズマ原虫作 用を有しないことを示唆している。イベルメクチン剂の 効能書には, 牛の内部寄生虫, および疥痽多二への効果 は謳われているものの，住血原虫への効果は示されてい ない。一方，一農場においてイベルメクチンを 5 年に亘 り投与し，著しくピロプラズマ陽性率を減少させた報告 があるが，この効果は主に動物の免度機能増強作用によ るもので，イベルメクチンの直接的な殺原虫作用とは考 えにくい7。しかし，牛体にイベルメクチン剂を投与する ことにより，フタトゲチマダニなどに効果があることを 示唆する報告や7,10), アフリカ産のダ二の寄生数を減少さ せる効果があるとの報告がある ${ }^{91}$ 今後イベルメクチン剂 を放牧衛生対策として用いる場合に，消化管内寄生虫へ の効果に加え，外部寄生虫駆除などへの効果があること も否定できない。

今回の試験では, 受胎までの人工授精回数などの受胎成 績において，イベルメクチン投与群と非投与群との間に 有意な差は認められなかった。類似する試験においては， 授精回数，初回種付け時の月齢などにおいて，消化管内 線虫を駆虫した群に良好な数值が報告されている かし, 受胎成績の変動には, 個体に特有の要因や人工授 精技術の差, 飼育方法, 環境要因, その他など, 各種の 要因が考えられ, 今回の試験の結果だけでは, イベルメ クチンの投与が受胎成績に影響があったかなかったかを 一概に結論づけるのは難しい。

今回の経済評価により，入牧時の月齢や体重が最も低 いCブロックにおいて,イベルメクチン投与が1頭当たり 9000円ほど便益が上がることが示唆された。しかし，他 のブロックにおいては大きな経済効果が得られず，当衛 生対策の経済的効果は入牧時の月齢などの影響を強く受
けるものと考えられた。今回の経済評価では，増体量の 数值を基に第一回の授精を行うまでに必要とされる放牧 日数の差を，放牧預託料で経済換算したが，一般的には 放牧衛生対策の経済性を算出するための指標として，増 体量あるいは初回種付けの許容体重到達までの日数がし ばしば用いられている3.13)。これは，これらの数值が比較 的算出が容易であり，またその数值に客観性があること などが理由に挙げられる。特に放牧育成牛の場合は，初 回種付けの許容体重到達までの日数の遅れにより，大き な経済的損失を生じることが報告されており ${ }^{3}$ ，放牧衛 生対策の経済性を推算するうえで重要な意味を持つ。さ らに，消化管内寄生虫の駆除の影響として，乳量や乳脂 肪率や無脂固形分量などが上昇することが報告されてい $3^{8.15 !}$ 。今回の試験では, 放牧牛の下牧後の追跡調査を行 うことが困難であったため，これらの数值を経済評価に 用いることができなかったが，これらの数值を用いるこ とにより，イベルメクチン剂投与の経済性がさらに上昇 する可能性もある。また, 他の線虫感染症の防除による 影響や免疫機能の変動による他の疾病への感受性の違い, 注射の牛体にかかる負担など，経済評価として算出の難 しい項目もあるが，今回はそれらの数值は経済評価に用 いなかった。

酪農先進諸国においてはかねてより消化管内線虫の問 題が取り上げられ，消化管内線虫を対象とした駆虫薬の 売上高が抗生物質をはるかに上まるほど重要視されてい るのに対し，わが国においては消化管内線虫の問題の重 要性はさほど認識されてこなかった。これは一般的に消 化管内線虫が顕著な臨床症状を示さず，その経済損失の 大きさが明確な形で生産者や獣医師に伝わらなかったこ とが一つの理由と考えられる2。 しかし近年，これらの事 を踏まえた消化管内線虫の経済的損失に関する再認識を 促寸論文や解説が增加してきている2 $23.8,13,15)$ 。今回の試験 で有効と見られた知見を元に，今後さらに内部寄生虫对 策に関連する他の各種の要因への影響や，本薬棛による 衛生対策の適切な投与時期, 方法, 回数の選択などにつ いて検討を重ねるべきである。

\section{要約}

埼玉県内の公共育成牧場において1995年度に入牧した 乳牛77頭について，イベルメクチン製剂投与による臨床 的効果，および経済効果を検討した。供試牛は入牧時月 齢および体重測定值の高い順から $\mathrm{A} ， \mathrm{~B}, \mathrm{C} の 3$ 試験群 に分け，その中で投与群（イベルメクチン 5 回投与）お よび非投与群を設定し, 日增体量, Ht值, 原虫陽転率, 受胎成績および経済効果について比較検討を行った。そ の結果，月齢の低い試験群で，イベルメクチン投与群が 
有意に高い日増体量と $\mathrm{Ht}$ 值を呈したが, 原虫陽転率およ び受胎成績などでは有意な差は認められなかった。イべ ルメクチン投与による放牧衛生対策は, 放牧育成牛の増 体量を上昇させ, 特に若齢の牛に用いた場合, その経済 効果が非常に高い事が示唆された。

\section{謝辞}

本研究に多大なるご協力を頂きました，塩野義製薬株式 会社動物薬品開発部佐々木滋室長及び関係者各位に深謝 いたします。

\section{参 考 文 献}

1 ) Campbell , W. C. ed.: Ivermectin and Abamectin, Springer-Verlag, New York, 1989

2 ) 福本真一郎：牛消化管内線虫症の重要性. 臨床獣医, 12, 13-20, 1996

3 ）桑本亮ら：公共育成牧場における標準発育の可能 性.畜産の研究, 7, 749-754,1996

4 ) 南哲郎, 藤永徹: 獣医住血微生物病. 近代出版, 東京, 163-169, 1986

5 ）宮本賢一ら：放牧育成牛における小型ピロプラズマ 病対策と発生状況について. 埼玉県家畜保健衛生業 績発表集録 第37報（平成 7 年度），117-122, 1995

6 ) 大石勇：犬糸状虫症予防の現状と最近の知見：特に ivermectinについて. 臨床獣医, 6, 94-98, 1987

7 ) 岡本浩介ら：イベルメクチン製剂によるピロプラズ マ病の清浄化とその経済効果について. 平成 6 年度 長野県家畜保健衛生業績発表会集録, 28-32, 1994
8 ）佐藤彰：乳牛の消化管内線虫による被害一駆虫に よる增乳効果一. 臨床獣医, 12, 28-35, 1996

9 ) Soll, M. D. et al.: Efficacy of ivermectin delivered from an intraruminal sustained-release bolus against natural infestations of five African tick species on cattle. Vet. Parasitol., 37, 285-296, 1990

10）高橋清志ら：Ivermectinのフタトゲチマダニに对 する駆除効果.第101回日本獣医学会抄録, 282, 1986

11）宇田川浩一ら：過去3年間の小型ピロプラズマ病予 防対策とその効果について。埼玉県家畜保健衛生業 績発表集録 第32報（平成2年度），138-148,1990

12) Williams, J. C. and Broussard, S. D.: Persistent anthelmintic activity of ivermectin against gastrointestinal nematodes of cattle. Am.J.Vet. Res., 9, 1169-1175, 1995

13）山根逸郎, 深沢芳隆, 小貫登輝夫：経済的に最も理 想的な衛生対策を選ぶ方法・4. 臨床獣医, 12, 44-50, 1996

14) Yazwinski, T. A. et al.: Residual nematocidal effectiveness of ivermectin in cattle. Am. J. Vet. Res., 10, 1416-1420, 1994

15）善波佳也ら：牛消化管内線虫駆除と生産性の改善. 臨床獣医, 12, 21-27, 1996

16）農林水産省農林水産技術会議事務局；日本飼育標準， 乳牛（1984年版）,114, 中央畜産会, 東京, 1994. 